\title{
PENGARUH PEMBERIAN KOMPENSASI DAN MOTIVASI KERJA TERHADAP EFEKTIVITAS KERJA KARYAWAN PADA PT BATIK DEWI BROTOJOYO TAHUN 2015
}

\author{
Mulyati \\ Guru SMAN 3 Sragen
}

\begin{abstract}
This study aims to: 1) determine whether there is a significant influence on the effectiveness of the compensation of employees in the batik industry Goddess Brotojoyo $2015 ; 2)$ determine whether there is a significant influence on the effectiveness of work motivation of employees at Industry batik Dewi Brotojoyo 2015;3) determine whether there is a significant effect compensation and work motivation on the effectiveness of employees in the batik industry Goddess Brotojoyo 2015. The population was are all employees of Industry Batik Dewi Brotojoyo in Masaran, some 225 employee. Method sampling technique used is produce random sampling proportional sample of 45 responden. Method analysis used in this study is the linear regression analysis ganda. Result tests performed showed that percentage physical work environment at PT. Batik Dewi Brotojoyo Masaran 2015 amounted to $76.8 \%$, the compensation amounting to $76.98 \%$, and the effectiveness of employees amounted to $78.43 \%$. From the calculation, the regression equation $9.766+0.228$ $\mathrm{X}_{1}+0.345 \mathrm{X}_{2}$. This means that the average effectiveness of employees (Y) is expected to increase or decrease by 0.228 for every one unit increase or decrease in the work environment and would have increased or decreased by 0.345 for every one unit increase or decrease the compensation.
\end{abstract}

Keywords: Provision of Compensation, Work Motivation, Work Effectiveness

\begin{abstract}
Abstrak: Penelitian ini bertujuan: 1) mengetahui ada tidaknya pengaruh yang signifikan pemberian kompensasi terhadap efektivitas kerja karyawan pada Industri batik Dewi Brotojoyo tahun 2015; 2) mengetahui ada tidaknya pengaruh yang signifikan motivasi kerja terhadap efektivitas kerja karyawan pada Industri batik Dewi Brotojoyo tahun 2015; 3) mengetahui ada tidaknya pengaruh yang signifikan pemberian kompensasi dan motivasi kerja terhadap efektivitas kerja karyawan pada Industri batik Dewi Brotojoyo tahun 2015. Populasi penelitian ini adalah adalah semua pegawai Industri Batik Dewi Brotojoyo di Masaran, sejumlah 225 pegawai. Metode pengambilan sampel yang digunakan adalah teknik proporsional random sampling menghasilkan sampel sebanyak 45 responden. Metode analisis yang digunakan dalam penelitian ini adalah analisis regresi linier ganda. Hasil pengujian yang dilakukan menunjukkan bahwa persentase lingkungan kerja fisik di PT. Batik Dewi Brotojoyo Masaran tahun 2015 adalah sebesar 76,8\%, pemberian kompensasi sebesar 76,98\%, dan efektivitas kerja karyawan sebesar 78,43\%. Dari hasil perhitungan diperoleh persamaan regresi $\hat{Y}=9,766+0,228 \mathrm{X}_{1}+0,345 \mathrm{X}_{2}$. Artinya bahwa rata-rata efektivitas kerja karyawan $(\mathrm{Y})$ diperkirakan meningkat atau menurun sebesar 0,228 untuk setiap ada peningkatan atau penurunan satu unit lingkungan kerja dan akan mengalami peningkatan atau penurunan sebesar 0,345 untuk setiap ada peningkatan atau penurunan satu unit pemberian kompensasi.
\end{abstract}

Kata kunci: Pemberian Kompensasi, Motivasi Kerja, Efektivitas Kerja 


\section{PENDAHULUAN}

Hakekat suatu organisasi didirikan adalah untuk mencapai tujuan yang telah ditetapkan. Guna meraih hasil yang telah ditetapkan maka organisasi dalam proses kegiatan melibatkan segala sumber daya yang dimiliki, baik sumber daya manusia maupun non manusia.

Salah satu unsur yang memegang peranan yang sangat penting dalam kehidupan organisasi dalam rangka pencapaian tujuan organisasi secara keseluruhan adalah unsur manusia sebagai sumber daya. Fasilitas lengkap dan teknologi mutakhir serta biaya yang besar tidak ada gunanya tanpa ada manusia yang mampu memanfaatkan, memelihara sarana dan fasilitas secara baik. Hal ini seperti dikemukakan oleh Indra Wijaya (2001:27) yang menyatakan bahwa:

Manusia dan hanya manusia satusatunya yang merupakan sumber utama organisasi yang tidak bisa digantikan dengan teknologi apapun. Bagaimana baiknya organisasi, lengkapnya prasarana dan fasilitas kerja, semuanya tidak akan mempunyai arti tanpa ada manusia yang mengatur, menggunakan, dan memeliharanya.

Dari pendapat di atas dapat disimpulkan bahwa unsur manusia sebagai sumber daya bagi organisasi mempunyai peranan yang sangat penting untuk menggerakkan semua aktivitas organisasi dalam rangka pencapaian tujuan.

Dalam menyelenggarakan aktivitas organisasi seperti yang diharapkan untuk mencapai tujuan organisasi, maka perlu tersedianya karyawan-karyawan sebagai sumber daya manusia yang berkualitas tinggi. Dalam rangka usaha untuk membentuk karyawan-karyawan sebagai sumber daya manusia yang berkualitas tinggi, maka diperlukan usaha-usaha pengembangan dan pembinaan terhadap para karyawan. Adanya pengembangan dan pembinaan terhadap para karyawan diharapkan akan terciptanya karyawan-karyawan yang berkualitas yang akan mendorong pada peningkatan efektivitas kerja karyawan.

Dalam setiap pelaksanaan kegiatan perlu diperhatikan efektivitas kerja karyawannya karena keberhasilan organisasi secara keseluruhan dimulai dari efektivitas kerja karyawannya. Efektivitas kerja merupakan salah satu hal untuk dapat menjaga kelangsungan hidup suatu organisasi. Efektivitas berkaitan dengan akibat yang dikehendaki. Hal ini berarti bahwa pelaksanaan kerja yang dilakukan harus dapat memberikan hasil yang sesuai dengan apa yang dikehendaki, yaitu hasil yang optimal dari para karyawan yang memanfaatkan potensi dan fasilitas yang ada.

Bagi organisasi tercapainya efektivitas kerja setiap karyawan merupakan hal yang sangat penting karena dengan tercapainya efektivitas kerja dari karyawannya, berarti akan memudahkan pencapaian tujuan organisasi. Untuk mencapai efektivitas kerja bukan suatu hal yang mudah, tetapi dipengaruhi berbagai faktor antara lain pemberian kompensasi, motivasi kerja, loyalitas karyawan dan lain sebagainya.

Salah satu usaha tercapainya efektivitas kerja karyawan adalah melalui pemberian kompensasi. Pemberian kompensasi kepada karyawan merupakan hal yang penting dalam organisasi dimana pengelolaan kompensasi menjadi tanggung jawab departemen Sumber Daya Manusia. Sampai sekarang masih sedikit dari bidang manajemen yang secara sungguh-sungguh mengkaji masalah kompensasi. Sebagai salah satu aspek pengembangan sumber daya manusia, kompensasi ini mempunyai tujuan yang cukup penting antara lain, untuk menarik karyawan yang berkualitas, mempertahankan karyawan, membangun komitmen karyawan dalam upaya meningkatkan kompetensi suatu perusahaan.

Kompensasi merupakan sarana yang diberikan perusahaan kepada karyawannya sebagai penghargaan atas kontribusi dan prestasi kerja mereka. Pemberian kompensasi 
yang diberikan perusahaan harus bersifat adil, baik itu adil secara internal maupun eksternal yaitu keseimbangan antara besarnya kompensasi yang diterima oleh karyawan dari perusahaan, sehingga perusahaan dapat meningkatkan efektivitas kerja karyawan dan mempertahankan keberadaan karyawan. Oleh karena itu perusahaan harus mampu memberikan rangsangan-rangsangan yang berupa pemberian kompensasi dalam bentuk uang maupun barang.

Kompensasi biasanya terdiri atas kompensasi langsung (Direct Compensation) dan kompensasi tidak langsung (Indirect Compensation). Tingkat-tingkat kompensasi yang diberikan organisasi kepada karyawan akan menentukan gaya hidup, status, harga diri dan perasaan terhadap organisasi.

Efektivitas kerja selain dipengaruhi oleh pemberian kompensasi juga tidak terlepas dari adanya motivasi kerja karyawan. Motivasi kerja merupakan sesuatu yang dapat menimbulkan semangat atau dorongan kerja oleh sebab itu motivasi kerja biasa disebut pendorong semangat kerja. Seperti dikemukakan oleh Susilo Martoyo (1999: 155) menyatakan bahwa, "Motivasi kerja adalah pendorong semangat kerja". Dengan demikian dapat dikatakan bahwa motivasi kerja itu adalah sesuatu yang menimbulkan dorongan bekerja yang berasal dari dalam diri karyawan dan juga berasal dari luar karyawan yang bersangkutan.

Dalam kenyataannya masalah motivasi masih jauh dari yang diharapkan. Pada umumnya para karyawan bersedia bekerja hanya termotivasi yang berasal dari dalam diri karyawan itu sendiri karena adanya gaji atau upah yang dapat digunakan untuk memenuhi kebutuhan hidupnya. Sedangkan motivasi yang berasal dari luar diri karyawan masih kurang dan perlu mendapat perhatian dari pihak manajer. Pihak manajer belum begitu sering memberikan motivasi meskipun motivasi itu berbentuk non materiil. Hal inilah yang akan berpengaruh pada efektivitas kerja karyawan. Oleh karena itu manajer yang memimpin bawahan harus dapat menciptakan motivasi yang tepat bagi setiap karyawan agar karyawan dapat lebih bersemangat dan bergairah di dalam bekerja sehingga memberikan hasil yang optimal dan tujuan organisasi dapat terealisir dengan baik.

Berdasarkan latar belakang yang peneliti paparkan di atas, tentang permasalahan yang dimiliki oleh karyawan mengenai pemberian kompensasi serta motivasi kerja karyawan yang mempengaruhi efektivitas kerja karyawan, maka peneliti terdorong untuk mengadakan penelitian tentang "Pengaruh Pemberian Kompensasi dan Motivasi Kerja Terhadap Efektivitas Kerja Karyawan Pada PT Batik Dewi Brotojoyo Tahun 2015”.

\section{Metodologi Penelitian}

Desain penelitian yang digunakan dalam penelitian ini adalah penelitian deskriptif. Teknik yang peneliti gunakan dalam penelitian ini adalah teknik penelitian proporsional random sampling. Sedangkan yang dimaksud dengan proporsional random sampling adalah pengambilan sampel secara proporsi (berdasarkan unsur atau kategorikategori tertentu) dari anggota populasi. Jadi dari populasi yang ada diambil sampelsampel yang sebanding dengan jumlah populasi dan pengambilannya secara rambang (proporsional random sampling). Dengan pengambilan sampel seperti ini, maka sampel yang terpilih dapat dipandang sebagai sampel yang benar-benar representatif, artinya dapat mencerminkan populasi secara maksimal.

Dalam penelitian ini peneliti mengambil sampel berjumlah 45 orang pegawai PT Batik Dewi Brotojoyo di Masaran secara proporsional random sampling, yaitu diambil sebesar 20\% dari jumlah pegawai PT Batik Dewi Brotojoyo di Masaran pada tiap bagian. Pengambilan sampel untuk tiap bagian tampak pada tabel sebagai berikut: 


\begin{tabular}{|c|c|c|c|c|}
\hline No & Bagian & $\begin{array}{c}\text { Jumlah } \\
\text { pegawai }\end{array}$ & Prosentase & $\begin{array}{c}\text { Jumlah } \\
\text { sampel }\end{array}$ \\
\hline 1 & Sekretariat & 20 & $20 \% \times 20=4$ & 4 \\
\hline 2 & Pemasaran & 45 & $20 \% \times 45=9$ & 9 \\
\hline 3 & Logistik & 35 & $20 \% \times 35=7$ & 7 \\
\hline 4 & Produksi & 80 & $20 \% \times 80=16$ & 16 \\
\hline 5 & $\begin{array}{c}\text { Keuangan } \\
\text { akuntansi }\end{array}$ & 30 & $20 \% \times 30=6$ & 6 \\
\hline 6 & $\begin{array}{c}\text { Devisi } \\
\text { umum }\end{array}$ & 15 & $20 \% \times 15=3$ & 3 \\
\hline & JUMLAH & 225 & $10 \% \times 120=12$ & 45 \\
\hline
\end{tabular}

Dari data yang telah terkumpul kemudian dianalisis dalam rangka pengujian hipotesis dan sebagai dasar untuk menarik kesimpulan. Adapun teknik analisis data yang digunakan dalam penelitian ini adalah teknik analisis regresi ganda.

Penggunaan teknik analisis korelasi regresi ganda ini sesuai dengan penelitian ini, hal ini karena dapat digunakan untuk mengetahui sejauh mana variabel dependen berpengaruh terhadap variabel independen. Adapun variabel dalam penelitian ini adalah: 1) Lingkungan kerja fisik $\left(X_{1}\right)$ dan 2) pemberian kompensasi $\left(\mathrm{X}_{2}\right)$ sebagai variabel bebas dan disebut juga prediktor. 3) Efektivitas kerja (Y) sebagai variabel tergantung dan disebut juga kriterium.

\section{Hasil Penelitian}

Penelitian ini membahas tentang pengaruh 2 variabel bebas yaitu lingkungan kerja fisik $\left(\mathrm{X}_{1}\right)$ dan pemberian kompensasi $\left(\mathrm{X}_{2}\right)$ terhadap satu variabel terikat yaitu efektivitas kerja karyawan (Y). Data ketiga variabel tersebut diperoleh melalui angket yang dilengkapi dengan menggunakan dokumen lain. Peneliti menggunakan angket sebagai teknik utama untuk pengumpulan data, mengenai lingkungan kerja fisik, pemberian kompensasi dan efektivitas kerja karyawan sedangkan dokumentasi untuk pengumpulan data jumlah karyawan yang diteliti dan struktur organisasi perusahaan.

Sebelum angket digunakan sebagai instrumen penelitian, terlebih dahulu dilakukan try out kepada 20 orang karyawan di luar sampel. Try out ini dimaksudkan untuk mengetahui adanya item-item yang tidak memenuhi validitas dan reliabilitas. Dari hasil uji validitas angket tentang lingkungan kerja fisik sebanyak 19 butir soal ada 2 soal yang tidak valid yaitu soal nomor 7 dan 12 . Hasil uji validitas angket tentang pemberian kompensasi sebanyak 20 butir soal, terdapat 2 item yang tidak valid 25 dan 37 . Hasil uji validitas tentang efektivitas kerja karyawan sebanyak 15 butir soal, juga terdapat dua item yang tidak valid, yaitu nomor 49 dan 52. Jadi keseluruhan item yang tidak valid dari 45 soal yang ditryoutkan ada 6 butir soal. Untuk nomor-nomor yang tidak valid untuk selanjut-nya tidak digunakan untuk mengambil data penelitian, karena sudah terwakili oleh item soal yang lain. Hasil perhitungan reliabilitas angket tentang lingkungan kerja fisik $=0,891$, reliabilitas angket pemberian kompensasi $=0,901$, dan reliabilitas angket efektivitas kerja karyawan $=0,850$. Karena harga reliabilitas lebih besar dari $r_{\text {tabel }}(0,444)$, maka hasil per-hitungan tersebut menunjukkan bahwa angket sudah reliabel untuk dijadikan alat penelitian.

Melalui proses tabulasi data lingkungan kerja fisik, pemberian kompensasi dan efektivitas kerja karyawan, maka peneliti mengemukakan deskripsi data sebagai berikut :

\section{Lingkungan Kerja Fisik}

Data lingkungan kerja fisik yang diperoleh dengan cara menyebarkan angket kepada 45 responden sebagai subyek penelitian, dapat diketahui :
a. Nilai tertinggi : 64
b. Nilai terendah : 38
c. Nilai Rata-rata : 52

Angket tentang lingkungan kerja fisik terdiri dari 17 pernyataan skala sikap yang pengukurannya dinilai dengan 4 alternatif jawaban dengan skor 1-4. Apabila dihitung dengan persentase maka akan diperoleh jumlah skor tertinggi sebesar $4 \times 17 \times 45=$ 3060. Jumlah skor hasil pengumpulan data lingkungan kerja fisik $\left(X_{1}\right)=2350$. Dengan 
demikian tingkat lingkungan kerja fisik di PT Batik Dewi Brotojoyo Masaran Sragen tahun 2015 sebesar 2350 : $3060=0,7680$ atau sebesar $76,8 \%$.

\section{Pemberian Kompensasi}

Pemberian kompensasi merupakan variabel bebas kedua $\left(\mathrm{X}_{2}\right)$. Data yang diperoleh menghasilkan nilai-nilai sebagai berikut:

a. Nilai tertinggi : 64

b. Nilai terendah : 44

c. Nilai rata-rata : 55

Angket tentang pemberian kompensasi terdiri dari 18 pernyataan skala sikap yang pengukurannya dinilai dengan 4 alternatif jawaban dengan skor 1-4. Apabila dihitung dengan persentase maka akan diperoleh jumlah skor tertinggi sebesar $4 \times 18 \times 45=$ 3240. Jumlah skor hasil pengumpulan data pemberian kompensasi $\left(\mathrm{X}_{2}\right)=2494$. Dengan demikian tingkat pemberian kompensasi di PT Batik Dewi Brotojoyo Masaran Sragen tahun 2007 sebesar $2494: 3240=0,7698$ atau sebesar 76,98\%.

\section{Efektivitas Kerja}

Efektivitas kerja karyawan merupakan variabel terikat (Y). Data yang diperoleh menghasilkan angka-angka sebagai berikut :

a. Nilai tertinggi : 47

b. Nilai terendah : 34

c. Nilai rata-rata : 41

Angket tentang efektivitas kerja terdiri dari 13 pernyataan skala sikap yang pengukurannya dinilai dengan 4 alternatif jawaban dengan skor 1-4. Apabila dihitung dengan persentase maka akan diperoleh jumlah skor tertinggi sebesar 4 × 13 × $45=2340$. Jumlah skor hasil pengumpulan data efektivitas kerja karyawan $(\mathrm{Y})=1836$. Dengan demikian tingkat efektivitas kerja karyawan di PT Batik Dewi Brotojoyo Masaran Sragen tahun 2015 sebesar $1836: 2340=0,7843$ atau sebesar $78,43 \%$.

\section{Hasil Pengujian Hipotesis}

Setelah dilakukan analisis data untuk pengujian hipotesis selanjutnya dilakukan penafsiran pengujian hipotesis. Penafsiran terhadap regresi linear hanya dapat dipertanggungjawabkan bila nilai $\mathrm{F}_{\text {reg }}$ yang diperoleh berarti atau signifikan. Penafsiran pengujian hipotesis yang dapat dikemukakan adalah sebagai berikut :

\section{Korelasi Antara $X_{1}$ Terhadap Y}

Berdasarkan analisis data yang telah dilakukan untuk mengetahui keberartian hubungan lingkungan kerja fisik $\left(\mathrm{X}_{1}\right)$ terhadap efektivitas kerja karyawan (Y) diperoleh hasil nilai $r_{\text {hit }}$ sebesar 0,454 dan $r_{\text {tabel }}$ sebesar 0,294. Jadi $r_{\text {hit }}>r_{\text {tabel }}$ atau 0,454 > 0,294, sehingga dapat ditafsirkan bahwa lingkungan kerja fisik berpengaruh terhadap efektivitas kerja karyawan. Pengaruh ini dapat dilihat dari besarnya sumbangan relatif lingkungan kerja fisik terhadap efektivitas kerja sebesar $41,78 \%$ dan sumbangan efektif sebesar $17,90 \%$ yang besarnya nilai sumbangan diperoleh dari aspek-aspek yang terdapat dalam lingkungan kerja fisik yang meliputi penerangan, pewarnaan, kebersihan, pertukaran udara, suara kebisingan, dan keamanan. Dari aspek-aspek di atas apabila terlaksana akan membantu karyawan dalam usahanya meningkatkan efektivitas kerja yang tinggi.

\section{Korelasi Antara $\mathrm{X}_{2}$ terhadap $\mathrm{Y}$}

Berdasarkan analisis data yang telah dilakukan untuk mengetahui keberartian hubungan pemberian kompensasi $\left(\mathrm{X}_{2}\right)$ terhadap efektivitas kerja karyawan (Y) diperoleh hasil $r_{\text {hitung }}$ sebesar 0,525 dan nilai $r_{\text {tabel }}$ sebesar 0,294, sehingga dapat ditafsirkan bahwa pemberian kompensasi berpengaruh terhadap efektivitas kerja karyawan. Pengaruh ini dapat dilihat dari besarnya sumbangan relatif pemberian kompensasi terhadap efektivitas kerja sebesar 58,22\% dan sumbangan efektif sebesar $24,94 \%$ yang besarnya nilai sumbangan diperoleh dari aspek-aspek yang terdapat dalam pemberian kompensasi yang meliputi aspek memenuhi 
kebutuhan minimal, mengikat, menimbulkan semangat dan kegairahan kerja, adil, dan tidak bersifat statis. Dari aspek-aspek di atas apabila terlaksana akan membantu karyawan dalam usahanya meningkatkan efektivitas kerja yang tinggi.

\section{Korelasi Multipel $\mathrm{X}_{1}$ dan $\mathrm{X}_{2}$ terhadap $\mathrm{Y}$}

Berdasarkan analisa data yang telah dilakukan untuk mengetahui keberartian atau pengaruh lingkungan kerja fisik dan pemberian kompensasi terhadap efektivitas kerja karyawan (Y) diperoleh hasil nilai $\mathrm{F}_{\text {hitung }}$ sebesar 15,74 dan nilai $F_{\text {tabel }}$ sebesar 3,22. Jadi $\mathrm{F}_{\text {hit }}>\mathrm{F}_{\text {tab }}$ atau 15,74 > 3,22 (lihat lampiran 28), sehingga dapat ditafsirkan bahwa lingkungan kerja fisik dan pemberian kompensasi berpengaruh terhadap efektivitas kerja karyawan. Ini berarti bahwa lingkungan kerja fisik dan pemberian kompensasi dapat mempengaruhi efektivitas kerja secara bersamasama. Berdasarkan hasil penelitian nilai $\mathrm{R}^{2}=$ 0,4284 . Hal ini berarti bahwa lingkungan kerja fisik dan pemberian kompensasi secara bersama-sama mempengaruhi efektivitas kerja karyawan sebesar $42,84 \%$ dan sisanya dijelaskan oleh variabel lain yang tidak diteliti pada penelitian ini.

\section{Persamaan Garis Regresi Linear Multipel}

Berdasarkan hasil analisis data yang telah dilakukan diperoleh persaman garis regresi linear ganda (lihat lampiran 29) sebagaiberikut :

$\hat{Y}=9,766+0,228 \mathrm{X}_{1}+0,345 \mathrm{X}_{2}$

Dari persamaan regresi tersebut di atas dapat ditafsirkan bahwa rata-rata efektivitas kerja karyawan (Y) diperkirakan akan meningkat atau menurun sebesar 0,228 untuk setiap ada peningkatan atau penurunan satu unit lingkungan kerja fisik dan akan mengalami peningkatan atau penurunan sebesar 0,345 untuk setiap ada peningkatan atau penurunan satu unit pemberian kompensasi.

\section{Kesimpulan Pengujian Hipotesis}

Setelah dilakukan pengujian hipotesis dan penafsiran pengujian hipotesis, maka selanjutnya dikemukakan kesimpulan pengujian hipotesis. Kesimpulan pengujian hipotesis yang dapat dikemukakan adalah sebagai berikut:

\section{Hipotesis 1}

Berdasarkan hasil pengujian hipotesis diperoleh nilai $r_{\text {hit }}>r_{\text {tab }}$ atau 0,454 $>0,294$, sehingga Ha diterima dan Ho ditolak pada taraf signifikansi 5\%. Jadi hipotesis pertama berbunyi "Ada pengaruh yang signifikan lingkungan kerja fisik terhadap efektivitas kerja karyawan PT Batik Dewi Brotojoyo Masaran Sragen tahun 2015", dapat diterima.

\section{Hipotesis 2}

Berdasarkan hasil pengujian hipotesis diperoleh nilai $r_{\text {hit }}>r_{\text {tab }}$ atau 0,525 $>0,294$, sehingga Ha diterima dan Ho ditolak pada taraf signifikansi 5\%. Jadi hipotesis kedua berbunyi "Ada pengaruh yang signifikan pemberian kompensasi terhadap efektivitas kerja karyawan PT Batik Dewi Brotojoyo Masaran Sragen tahun 2015", dapat diterima.

\section{Hipotesis 3}

Berdasarkan hasil pengujian hipotesis diperoleh $\mathrm{F}_{\text {hit }}>\mathrm{F}_{\text {tab }}$ atau 15,74 $>3,22$, sehingga Ha diterima dan Ho ditolak pada taraf signifikansi 5\%. Jadi hipotesis ketiga berbunyi “Ada pengaruh lingkungan kerja fisik dan pemberian kompensasi terhadap efektivitas kerja karyawan PT Batik Dewi Brotojoyo Masaran Sragen 2015", dapat diterima.

\section{Pembahasan}

Pembahasan hasil penelitian ini adalah sebagai berikut :

\section{Lingkungan Kerja Fisik}

Berdasarkan hasil pengumpulan data, setelah diolah skor rata-rata lingkungan kerja fisik adalah 76,8\%. Dengan ini dapat dikatakan bahwa PT Batik Dewi Brotojoyo menciptakan lingkungan kerja fisik sebesar 
$76,8 \%$, yang berarti masih dapat ditingkatkan lagi. Apabila lingkungan kerja fisik dapat diciptakan dengan lebih baik, maka karyawan akan dapat melakukan pekerjaan tanpa menghadapi kendala yang berarti, sehingga meningkatkan efektivitas kerjanya yang pada akhirnya juga meningkatkan efektivitas perusahaan secara keseluruhan.

Karena baru tercapai sebesar $76,8 \%$ berarti masih ada hal-hal yang belum terpenuhi. Hal-hal tersebut dapat dilihat dari item-item dalam daftar angket yang nilainya rendah, antara lain item no. 5 yaitu tentang kesesuaian warna dengan kondisi mata karyawan. Dengan adanya kondisi tersebut berarti perusahaan masih belum dapat memenuhi kebutuhan warna ruang yang sesuai dengan kondisi mata karyawan yang bekerja di ruang tersebut.

\section{Pemberian Kompensasi}

Berdasarkan hasil pengumpulan data setelah diolah skor rata-rata pemberian kompensasi adalah 76,98\%. Dengan ini dapat dikatakan bahwa PT Batik Dewi Brotojoyo memberikan kompensasi kepada karyawan sebesar 76,98\%. Karena baru tercapai sebesar $76,98 \%$ berarti masih ada kompensasi yang dirasakan oleh karyawan belum mencukupi. Bila kompensasi yang kurang tersebut dapat dipenuhi, maka karyawan dapat bekerja dengan lebih baik lagi.

Hal-hal yang belum dapat terpenuhi lainnya bisa dilihat dari daftar angket yang rendah nilainya item nomor 31 yaitu kesesuaian antara kompensasi yang diberikan oleh perusahaan dengan beban kerja karyawan. Hal ini berarti bahwa pemberian kompensasi yang sesuai dengan tingkat beban kerja pada PT Batik Dewi Brotojoyo belum terlaksana dengan maksimal. Adanya hal tersebut diperkirakan karena perusahaan dalam menetapkan besarnya kompensasi masih kurang memperhatikan hasil kerja karyawan. Dengan adanya hal tersebut maka perusahaan perlu melakukan kajian ulang tentang kebijaksanaannya dalam memberikan kompensasi kepada karyawan.

\section{Efektivitas Kerja Karyawan (Y)}

Berdasarkan pengumpulan data, setelah diolah skor rata-rata efektivitas kerja adalah sebesar 78,43\%. Dengan pencapaian tingkat efektivitas kerja sebesar 78,43\% dapat dikatakan bahwa tingkat efektivitas kerja karyawan PT Batik Dewi Brotojoyo masih dapat ditingkatkan lagi sesuai dengan kemampuan karyawan masing-masing. Karena belum mencapai $100 \%$, maka sisanya yang belum terpenuhi bisa dilihat dari daftar angket yang nilainya paling rendah yaitu item no 50 dengan skor 131, yaitu item tentang pemanfaatan waktu luang sebelum jam kerja berakhir. Hal ini menunjukkan bahwa bila karyawan sudah selesai melaksanakan tugasnya, banyak karyawan yang tidak menunggu jam kerja berakhir. Bila melihat tingkat lingkungan kerja fisik sebesar 76,8\% dan pemberian kompensasi 76,98\% maka efektivitas kerja karyawan tersebut dapat ditingkatkan lagi, dengan meningkatkan kondisi lingkungan kerja fisik dan pemberian kompensasi yang sesuai dengan hasil kerja karyawan.

Berdasarkan hasil yang telah dicapai, peneliti beranggapan bahwa penelitian ini menunjukkan efektivitas kerja karyawan tidak hanya dipengaruhi oleh variabel yaitu lingkungan kerja fisik dan pemberian kompensasi melainkan juga dapat dipengaruhi oleh variabel lainnya yang tidak tercakup dalam penelitian ini. Hal ini dapat dilihat dari besarnya koefisien determinasi sebesar 0,4284 yang berarti kedua variabel penelitian, yaitu lingkungan kerja fisik dan pemberian kompensasi memberikan pengaruh sebesar $42,84 \%$ terhadap efektivitas kerja. Karena kedua variabel memberikan pengaruh sebesar $42,84 \%$, maka masih ada $57,16 \%$ variabel lain yang mempengaruhi efektivitas kerja. Variabel-variabel lain tersebut antara lain kepemimpinan, pengawasan, kondisi peralatan, motivasi kerja, dan masih ada kemungkinan variabel lain yang belum diketahui. 


\section{PENUTUP}

\section{Simpulan}

Berdasarkan hasil analisis data dan pengujian hipotesis, kesimpulan dari penelitian ini adalah:

1. Ada pengaruh yang signifikan lingkungan kerja fisik terhadap efektivitas kerja karyawan di PT. Batik Dewi Brotojoyo Masaran Sragen tahun 2015.

2. Ada pengaruh yang signifikan pemberian kompensasi terhadap efektivitas kerja karyawan di PT. Batik Dewi Brotojoyo Masaran Sragen tahun 2015.

3. Ada pengaruh yang signifikan lingkungan kerja fisik dan pemberian kompensasi terhadap efektivitas kerja karyawan di PT. Batik Dewi Brotojoyo Masaran Sragen tahun 2015.

Berdasarkan data yang terkumpul dan hasil analisis data yang telah dilakukan dapat juga diperoleh temuan lain yang berhubungan dengan ketiga variabel yaitu lingkungan kerja fisik, pemberian kompensasi, dan efektivitas kerja karyawan. Temuan lain tersebut antara lain adalah:

1. Persentasi lingkungan kerja fisik di PT. Batik Dewi Brotojoyo Masaran tahun 2015 adalah sebesar $76,8 \%$, pemberian kompensasi sebesar 76,98\%, dan efektivitas kerja karyawan sebesar $78,43 \%$.

2. Dari hasil perhitungan diperoleh persamaan regresi :

$\hat{Y}=9,766+0,228 \mathrm{X}_{1}+0,345 \mathrm{X}_{2}$

Artinya bahwa rata-rata efektivitas kerja karyawan (Y) diperkirakan meningkat atau menurun sebesar 0,228 untuk setiap ada peningkatan atau penurunan satu unit lingkungan kerja dan akan mengalami peningkatan atau penurunan sebesar 0,345 untuk setiap ada peningkatan atau penurunan satu unit pemberian kompensasi.

3. Besarnya sumbangan relatif dan efektif berdasarkan hasil pengujian hipotesis adalah sebesar:

a. Sumbangan relatif variabel lingkungan kerja fisik sebesar $41,78 \%$. b. Sumbangan relatif variabel pemberian kompensasi sebesar $58,22 \%$.

c. Sumbangan efektif variabel lingkungan kerja fisik sebesar $17,90 \%$.

d. Sumbangan efektif variabel pemberian kompensasi sebesar $24,94 \%$.

\section{Saran}

Berdasarkan pembahasan hasil analisis data dan simpulan yang telah peneliti sajikan di atas, peneliti dapat memberikan saransaran yang diharapkan dapat memberikan manfaat bagi organisasi maupun bagi karyawannya. Adapun saran-saran yang dapat peneliti sampaikan adalah sebagai berikut :

\section{Bagi Pimpinan}

a. Berdasarkan pada hasil angket, skor terendah lingkungan kerja fisik menunjukkan bahwa perusahaan belum dapat menyediakan pewarnaan ruangan yang sesuai dengan kondisi karyawan. Warna ruangan sebaiknya warna krem karena warna krem tidak menyilaukan mata namun tetap mencerminkan warna terang.

b. Berdasarkan hasil angket pemberian kompensasi menunjukkan bahwa pemberian kompensasi belum sesuai dengan beban kerja. Sebaiknya pemberian kompensasi untuk tahun depan dinaikkan sesuai dengan beban kerja.

c. Pada hasil angket tentang efektivitas kerja, diketahui skor terendah adalah tentang pemanfaatan jam luang sebelum jam kerja berakhir. Dengan rendahnya skor pada item tersebut menunjukkan bahwa jika tidak ada pekerjaan, banyak karyawan yang tidak menunggu sampai jam kerja berakhir. Hal ini berarti bahwa bila karyawan dapat menyelesaikan pekerjaan lebih cepat dari yang diperkirakan, mereka langsung pulang tanpa menunggu jam kerja berakhir. Untuk menambah pengetahuan para karyawan sebaiknya PT Batik Dewi Brotojoyo menyediakan ruang untuk perpustakaan. 


\section{Kepada Karyawan}

Berdasarkan hasil angket bahwa skor terendah tingkat efektivitas kerja karyawan adalah tentang pemanfaatan waktu luang sebelum jam kerja berakhir, maka hal ini menunjukkan bahwa sebagian karyawan dapat mengerjakan pekerjaan secara efektif, sehingga masih ada waktu luang yang tersisa. Sebaiknya waktu luang yang ada dimanfaatkan untuk mengoreksi ulang hasil pekerjaannya yang belum sempurna. Misalnya mengecek batik yang sudah disablon kalau ada yang ciri/cacat, bagi karyawan yang sudah selesai pekerjaannya sebaiknya membantu karyawan lainnya yang belum selesai pekerjaannya.

\section{DAFTAR PUSTAKA}

Abi Sujak. 1990. Kepemimpinan Manajer, Eksistensinya dalam Perilaku Organisasi. Jakarta : Bumi Aksara.

Alex S. Nitisemito. 1996. Manajemen Personalia. Jakarta: Ghalia Indonesia.

Cholid Narbuko dan Abu Ahmadi. 2002. Metodologi Penelitian. Jakarta : Bumi Aksara.

Djarwanto P. S. dan Pangestu Subagya. 2002. Pokok-Pokok Metode Riset dan Bimbingan Teknis Penulisan Skripsi. Yogyakarta: Liberty.

Gerry Desler. 1998. Human Resources Management. New Jersey: Prentice Hall, Inc.

Hadari Nawawi dan Martini Hadari. 1990. Administrasi Personalia untuk Peningkatan Produktivitas Kerja. Jakarta : Haji Masagung.

Hadari Nawawi. 1997. Ilmu Administrasi. Jakarta : Ghalia Indonesia.

Hadi Pramono. 1990. Hubungan Kerja antara Majikan dan Buruh. Jakarta : Bina Aksara.
Kartini Kartono. 1994. Pemimpin dan Kepemimpinan. Jakarta : PT. Raja Grafindo Persada.

Kartini Kartono. 1996. Metodologi Riset Sosial. Jakarta: LP3ES.

Kustartini. 1986. Pokok Pikiran Perbaikan Hasil Kerja. Yogyakarta: BPA UGM.

Steers, Richard M. 1990 Efektivitas Organisasi. Terjemahan : Magdalena Jamin. Jakarta : Erlangga.

Malayu S.P. Hasibuan. 2003. Manajemen Sumber Daya Manusia. Jakarta: Haji Masagung.

Mardiyana. 1998. Manajemen Produksi. Jakarta : Badan Penerbit IPWI.

Masri Singarimbun dan Soffian Efendi. 1995. Metodologi Penelitian Survey. Jakarta : LP3ES.

Moekijat. 1992. Manajemen Kepegawaian. Bandung: Alumni.

Moh. As'ad. 1999. Psikologi Industri. Yogyakarta: Liberty.

Moh. Nazir. 2003. Metode Penelitian. Jakarta: Ghalia Indonesia.

Mulia Nasution. 1994. Manajemen Personalia Aplikasi dalam Perusahaan. Jakarta : Djambatan.

Nainggolan. 1983. Pembinaan Pegawai Negeri Sipil. Jakarta : BAKN.

Sarwoto. 1991. Dasar-dasar Organisasi dan Manajemen. Jakarta : Ghalia Indonesia.

Soekanto dan Indriyo. 2000. Lingkungan Kerja. Jakarta : Bina Aksara.

Sondan P. Siagian. 1994. Pengelolaan Sumber Daya Manusia. Jakarta : SIUP.

Heidjrachman Ranupandojo dan Suad Husnan. 2002. Manajemen Personalia. Yogyakarta: BPFE. 
Sudjana. 2002. Analisis Regresi dan Korelasi. Bandung: Tarsito.

Suharsimi Arikunto. 2002. Prosedur Penelitian Suatu Pendekatan Praktik. Jakarta: Rineka Cipta.

Sumadi Suryabrata. 1997. Metodologi Penelitian. Jakarta : Rajawali Pers.

Susilo Martoyo. 2000. Manajemen Administrasi. Bandung: Alfabeta.

Sutrisno Hadi. 1991. Metodologi Research I. Yogyakarta : Fakultas Psikologi UGM.
Sutrisno Hadi. 1999. Metodologi Research II. Yogyakarta : Fakultas Psikologi UGM.

Sutrisno Hadi. 2002. Analisis Regresi. Yogyakarta: Andi Offset.

The Liang Gie. 1992. Pengertian Kedudukan dan Perincian Ilmu Administrasi. Yogyakarta : Karya Kencana.

Winarno Surakhmad. 1998. Pengantar Penelitian Ilmiah Dasar Metode Teknik. Bandung : Tarsito. 